\title{
Epithelial-to-Mesenchymal Transition and Cancer Invasiveness: What Can We Learn from Cholangiocarcinoma?
}

\author{
Simone Brivio ${ }^{1}$, Massimiliano Cadamuro ${ }^{1,2}$, Luca Fabris ${ }^{2,3}$ and Mario Strazzabosco ${ }^{1,3, *}$ \\ Received: 19 November 2015; Accepted: 14 December 2015; Published: 19 December 2015 \\ Academic Editors: David A. Brenner, Tatiana Kisseleva and Jonas Fuxe \\ 1 School of Medicine and Surgery, University of Milan-Bicocca, Via Cadore 48, 20900 Monza, Italy; \\ s.brivio3@campus.unimib.it (S.B.); massimiliano.cadamuro@gmail.com (M.C.) \\ 2 Department of Molecular Medicine, University of Padua School of Medicine, Viale Colombo 3, 35131 Padua, \\ Italy; luca.fabris@unipd.it \\ 3 Liver Center, Section of Digestive Diseases, Yale University, TAC Building, 333 Cedar Street, New Haven, \\ CT 06520, USA \\ * Correspondence: mario.strazzabosco@yale.edu or mario.strazzabosco@unimib.it; Tel.: +39-02-6448-8052
}

\begin{abstract}
In addition to its well-established role in embryo development, epithelial-to-mesenchymal transition (EMT) has been proposed as a general mechanism favoring tumor metastatization in several epithelial malignancies. Herein, we review the topic of EMT in cholangiocarcinoma (CCA), a primary liver cancer arising from the epithelial cells lining the bile ducts (cholangiocytes) and characterized by an abundant stromal reaction. CCA carries a dismal prognosis, owing to a pronounced invasiveness and scarce therapeutic opportunities. In CCA, several reports indicate that cancer cells acquire a number of EMT biomarkers and functions. These phenotypic changes are likely induced by both autocrine and paracrine signals released in the tumor microenvironment (cytokines, growth factors, morphogens) and intracellular stimuli (microRNAs, oncogenes, tumor suppressor genes) variably associated with specific disease mechanisms, including chronic inflammation and hypoxia. Nevertheless, evidence supporting a complete EMT of neoplastic cholangiocytes into stromal cells is lacking, and the gain of EMT-like changes by CCA cells rather reflects a shift towards an enhanced pro-invasive phenotype, likely induced by the tumor stroma. This concept may help to identify new biomarkers of early metastatic behavior along with potential therapeutic targets.
\end{abstract}

Keywords: cholangiocarcinoma; cholangiocyte; epithelial-to-mesenchymal transition; invasiveness; metastatization; tumor reactive stroma; cancer-associated fibroblast

\section{Introduction}

Cholangiocarcinoma (CCA) is a primary liver cancer arising from the epithelial cells lining the intra and extrahepatic portions of the biliary tree (cholangiocytes). Although classically viewed as a relatively rare type of cancer, CCA is responsible for $10 \%-20 \%$ of the deaths related to primary liver malignancies, and its incidence has progressively increased starting from the early 1990s, at least for the intrahepatic variant. Unlike hepatocellular carcinoma, CCA does not usually develop within a background of chronic liver disease, which makes its diagnosis and treatment even more difficult [1]. In fact, CCA is most often diagnosed at an advanced stage, when intrahepatic or lymph node metastatic dissemination has already occurred, owing to the strong and early invasiveness of the tumor. Therefore, less than one-third of patients are eligible for radical surgery, which is, so far, the only treatment with curative intent, whereas most of them are merely located to palliative procedures. Unfortunately, the success of surgical resection is heavily threatened by the high rates of recurrence, resulting in a five-year 
survival of no more than $20 \%-30 \%$. On the other hand, in the last few years liver transplantation has been proposed, but only for a highly selected subset of patients and by few specialized centers [2-4].

Overall, these gaps in knowledge support the need to better understand the molecular mechanisms underlying the invasive properties of CCA, with the ultimate goal to identify biomarkers of early metastatic behavior, useful for the decision-making process of patient allocation to the best treatment, and to develop targeted molecular therapies aimed at halting the metastatic spread of the tumor. In the last few years, growing attention has been drawn on epithelial-to-mesenchymal transition (EMT) as a mechanism promoting dissemination in several cancer cell types.

\section{EMT Involvement in Cancer Cell Dissemination}

Metastasis is a complex and continuously evolving process, which follows a specific sequence of events. In solid epithelial cancers, the cell metastatization follows four steps:

(1) Detachment from the highly-organized epithelial layer; this requires reducing cell-cell contacts and rearranging the cytoskeletal architecture, in favor of a motile phenotype;

(2) Impairment of the integrity of the basement membrane through active proteolysis, and then invasion of the surrounding stroma as strands or cords. Once in the tumor stroma, cells can efficiently cross-talk with multiple mesenchymal and inflammatory cell types, which in turn support their invasiveness;

(3) Dissemination at distance through the lymphatic and/or hematogenous circulation, taking advantage of the leaky neovasculature arising in the tumor microenvironment; and

(4) Engraftment at the distant sites by moving from the vessel lumen into the ectopic tissue parenchyma, wherein cells restart their deregulated proliferative program $[5,6]$.

As a general concept, the metastatic cascade relies, at least partially, on the activation by the cancer cell of molecular programs typical of the mesenchymal lineage, as shown by profound changes in the expression of cytoskeletal and cell surface proteins, as well as by de novo expression of extracellular matrix (ECM)-degrading enzymes [7]. This observation led many researchers to speculate that carcinoma cells undergoing metastatization may somehow recapitulate the embryonic program of phenotypic conversion known as EMT [8]. During morphogenetic EMT, differentiated epithelial cells gradually acquire a full mesenchymal phenotype, characterized by the disassembly of cell junctions and the loss of cytokeratin filaments, with a concomitant gain of migratory functions, by which cells may leave their original localization within the epithelial sheets $[9,10]$. Through EMT, a number of key developmental events, such as embryo implantation, gastrulation and neural crest formation, can properly occur [11]. The EMT process is driven by a set of embryonic transcription factors, including Snail (Snail1), Slug (Snail2), Twist1/2 and ZEB1/2, which repress the expression of cytokeratins (K) and critical junction proteins, in particular E-cadherin, the molecular hallmark of the epithelial phenotype. On the same time, these transcription factors variably induce the expression of a range of mesenchymal markers, such as $\alpha$-smooth muscle actin ( $\alpha$-SMA), vimentin, and S100A4. Moreover, increased production of ECM components, such as fibrillar collagen, and of matrix metalloproteinases (MMPs) is concurrently shown by cells undergoing EMT [12-14]. Activation of pro-EMT transcription factors is triggered by a broad spectrum of factors, encompassing cytokines and growth factors (such as transforming growth factor (TGF)- $\beta 1$ and growth factors with affinity for receptor tyrosine kinases) [14,15], morphogenetic signals (namely Wnt, Notch and Hedgehog (Hh) signaling) [16], and post-transcriptional gene regulator microRNAs (miRNA) (e.g., miR-200 family members) [17]. These triggering factors can be released as effect of several disease mechanisms, in particular chronic inflammation, hypoxia and autophagy, most of which may be involved in malignant transformation [18-20]. 


\section{Evidence for EMT in Human Carcinomas}

The ability of tumor cells to express at different levels some mesenchymal properties is largely recognized. These include the loss of cell-to-cell adhesion (usually modulated by the E-cadherin to N-cadherin switch), alterations in cell polarity (from apical-basal to front-rear) and cell shape (from cobblestone-like to spindle-like), expression of mesenchymal biomarkers, such as vimentin and S100A4, and proteolytic activities [21,22]. Notably, cells expressing EMT biomarkers are more frequently localized at the invasive front rather than in the bulk of the tumor $[9,23]$. Nonetheless, EMT signatures (that we would rather call "transitional" properties) have been widely reported in circulating tumor cells $[24,25]$, thus highlighting the concept that these "transitional" properties identify a subset of tumor cells more prone to be engaged in invasive processes. Furthermore, many clinical studies correlated the expression of EMT features with an increased metastatic potential and a poor clinical outcome in several carcinomas, including breast [26,27], pancreatic [28], gastric [29], colorectal [30], and lung cancer [31]. This clinical evidence is consistent with experimental data, showing the ability of TGF- $\beta 1$, Snail and Twist, to induce the expression of mesenchymal features in human cultured cancer cell lines, in vitro [32-35], and to enhance their metastatic potential in xenograft models [36-38]. Notwithstanding, the actual relevance of EMT in human tumor progression still remains uncertain. In this regard, CCA is an epithelial cancer type with several peculiarities particularly suitable to address this issue.

\section{Expression of EMT Features in CCA and Underlying Mechanisms Involved}

Phenotypic features of EMT, including up-regulation of vimentin, S100A4, Snail and Twist, in conjunction with down-regulation of E-cadherin and of membranous $\beta$-catenin, have been observed in neoplastic bile ducts [39]. Most of them frequently correlated with tumor progression and more severe prognosis [40-43]. For example, low expression of E-cadherin in CCA tissues, significantly associated with the presence of metastasis, and tended to correlate with a shorter survival time [44]. In this context, our group recently showed that S100A4, when expressed in the nucleus of neoplastic bile ducts, is a strong predictor of increased invasiveness and metastatization in CCA patients. Moreover, we demonstrated that relevance of nuclear S100A4 went well beyond that of a mere surrogate marker of invasiveness, as it was functionally able to promote the acquisition of a metastatic phenotype. Indeed, human CCA cells harboring nuclear expression of S100A4 displayed increased metastatic abilities when xenotransplanted into SCID mice, compared with CCA cells not expressing S100A4 in the nucleus. Mechanistic relevance of S100A4 was further supported by in vitro studies showing that down-modulation of nuclear S100A4 in CCA cells by lentiviral silencing or by pharmacological treatment with paclitaxel significantly reduced their motility and invasive functions. These effects were associated with a reduction in the activities of Rho-A and Cdc42, small Rho GTPases known to affect the directionality of cell migration, and of MMP-9, a pivotal proteolytic enzyme in cancer invasiveness [7,45]. Factors modulating the ability of CCA cells to express different "transitional" features are gradually emerging and, potentially, may provide a target of therapeutic intervention to halt CCA invasiveness. Under their effect, the up-regulation of EMT markers goes hand in hand with increased cell invasiveness, in vitro.

\subsection{Cytokines, Growth Factors and Morphogens Promoting EMT}

Multiple soluble factors are able to induce a "transitional" phenotype in cultured CCA cells. They are summarized in Table 1. These factors are variably released into the tumor microenvironment by different cell sources, supporting involvement of both autocrine and paracrine mechanisms. In fact, besides tumoral cells, cells recruited within the tumor reactive stroma (TRS), closely aligning with the neoplastic ducts, may be also strong producers of EMT inducers. The TRS is a highly-specialized mesenchymal compartment hosting several cell types, such as cancer-associated fibroblasts (CAFs) and tumor-associated macrophages (TAMs), which provide cancer cells with a broad range of cues 
directly stimulating their malignant behavior [46]. In fact, CAFs secrete high levels of TGF- $\beta$, IL-6, SDF-1, EGF, and FGF, whereas TAMs variously produce TGF- $\beta$, TNF- $\alpha$, IL- 6 , and EGF. Moreover, either cell types may release several MMPs, able to trigger EMT changes by cleaving essential cell adhesion molecules on the surface of cancer cells $[46,47]$. Human CCA cells cultured with conditioned media harvested from activated macrophages actually showed a strong down-regulation of E-cadherin and K-19, in conjunction with an up-regulation of S100A4 and MMP-9 [48], and with increased migratory properties, in vitro [49]. Similarly, SDF-1 produced by CAFs, was reported to promote the invasiveness of cultured CCA cells, marked by de novo expression of vimentin, and decreased expression of E-cadherin and membranous $\beta$-catenin [50]. Similar evidence was reported in other cancers featuring an abundant desmoplasia, such as breast [51] and colorectal [52] cancer. Of note, the hypoxic microenvironment typically featuring CCA has been proposed as an important stressor exacerbating the release of EMT inducers [53]. For example, hypoxia may induce the secretion of the multifunctional peptide adrenomedullin (ADM) by CCA cells. ADM overexpression was observed in neoplastic bile ducts, and, in vitro, it associated with the induction of tumor cell migration and invasion via EMT [54].

Table 1. Soluble factors inducing a "transitional" phenotype in cultured CCA cells.

\begin{tabular}{cc}
\hline EMT Inducer & References \\
\hline \multicolumn{2}{c}{ Inflammatory cyto/chemokines } \\
TGF- $\beta 1$ & {$[55-58]$} \\
TNF- $\alpha$ & {$[59]$} \\
IL-6 & {$[60]$} \\
HMGB1 & {$[61]$} \\
SDF-1 & {$[50]$} \\
EGF & Growth factors \\
FGF-19 & {$[62,63]$} \\
Notch1/Sox9 & {$[64]$} \\
Sonic Hh & {$[65-67]$} \\
\hline
\end{tabular}

Transforming growth factor $\beta 1$, TGF- $\beta 1$; tumor necrosis factor $\alpha$, TNF- $\alpha$; interleukin 6 , IL-6; high-mobility group box 1, HMGB1; stromal cell-derived factor 1, SDF-1; epidermal growth factor, EGF; fibroblast growth factor 19, FGF-19; Hedgehog, Hh.

Several epigenetic mechanisms, including DNA methylation and histone post-translational modifications, have been hypothesized to regulate the expression of EMT-related signatures, in line with the concept of pronounced plasticity of tumoral cells that may dynamically adapt to various microenvironmental stimuli [69]. For example, Snail-induced E-cadherin repression is mediated, at least in part, by the direct recruitment of both histone deacetylases and DNA methyltransferases at the E-cadherin promoter $[70,71]$. The ability to induce epigenetic changes in co-cultured cancer cells has been reported in CAFs from gastric, ovarian and breast cancer [72-74]. In particular, CAFs from gastric cancer induced in tumoral cells a down-modulation of E-cadherin coupled with increased migratory functions through a DNA methylation-dependent inactivation of miR-200b (see below), which led to ZEB1/2 activation [72]. It is tempting to speculate that similar epigenetic events may also occur in CCA, possibly driven by interactions with the TRS components $[12,46]$, an issue worthy of particular attention by future studies.

\section{2. miRNAs Promoting EMT}

miRNAs are endogenous non-coding RNAs of 20-25 nucleotides, which regulate mostly negatively gene expression by directly interacting with target mRNAs, thus inhibiting their translation and/or promoting their cleavage. Besides their involvement in physiological processes, increasing evidence suggests that several miRNAs play a pathogenic role in human cancers, as highlighted by 
the differential expression profiles between tumor and normal tissues. Indeed, most of miRNA genes are located within cancer-associated genomic regions [75]. Several miRNAs have been found to be deregulated in human CCA cell lines and/or tissues, wherein they affect a wide range of processes related to tumor biology, such as proliferation (e.g., miR-21, miR-26a, miR-31, miR-421, miR-494), apoptosis (e.g., miR-21, miR-25, miR-29b, miR-31, miR-204, miR-320), migration (e.g., miR-21, miR-138, miR-200b, miR-220c, miR-376c, miR-421), differentiation (e.g., miR-200b, miR-373), angiogenesis (e.g., miR-101) and chemoresistance (e.g., miR-21, miR-29b, miR-200b, miR-205, miR-221) [76,77]. In this regard, recent studies have shown that inactivation of specific miRNAs may also induce an EMT phenotype. Those found inactivated in CCA cells and their EMT-related target genes are illustrated in Table 2. Among them, neural cell adhesion molecule (NCAM) is a surface glycoprotein expressed by immature cholangiocytes and functionally linked to EMT, and Smad4 is a common downstream effector of the TGF- $\beta$ pathway. Conversely, miR-21 promotes EMT changes when aberrantly activated [78]. Noteworthy, the expression of miR-214, miR-204 and miR-34a was significantly reduced in CCA specimens, compared with normal tissues, and their down-regulation closely correlated with CCA metastasis.

Table 2. miRNAs whose inactivation leads to EMT induction.

\begin{tabular}{ccc}
\hline miRNA & Target Gene & References \\
\hline miR-214 & Twist & {$[79]$} \\
miR-204 & Slug & {$[80]$} \\
miR-200c & ZEB1/2; NCAM & {$[81]$} \\
miR-34a & Smad4 & {$[82]$} \\
\hline
\end{tabular}

Neural cell adhesion molecule, NCAM.

\subsection{Oncogenes and Tumor Suppressor Genes Regulating EMT}

An altered expression of both oncogenes and tumor suppressor genes may also entail EMT changes promoting CCA metastatization. Among oncogenes, the zinc finger transcription factor spalt-like transcription factor 4 (SALL4) [83], and the transcriptional co-activator yes-associated protein (YAP) [84], are found to play a relevant role in CCA. SALL4 ability to induce mesenchymal properties relates to its well-documented interactions with TGF- $\beta$ and Wnt signaling pathways [85], whereas YAP triggers EMT by increasing the expression of the oncoprotein gankyrin in an AKT-dependent manner [84]. With respect to tumor suppressor genes, two recent studies have shed light on the role of the ubiquitin ligase F-box and WD repeat domain-containing 7 (FBXW7), and of the protein kinase mitogen-activated protein 3 kinase 4 , as negative regulators of mTOR/ZEB1 and p38/NF-kB/Snail pathways, respectively [86,87]. Importantly, the role of YAP and FBXW7 in CCA invasiveness was confirmed also in vivo by xenograft models, where YAP overexpression or FBXW7 knockdown led to an increased cancer dissemination. In gallbladder cancer (GBC), the most common malignancy of the biliary tract, pathologically distinct from CCA, but characterized by a similar invasive phenotype, occurrence of EMT-like changes has been recently linked to the newly identified tumor suppressor gene $N$-myc downstream-regulated gene (NDRG)-2. GBC cells with loss of NDRG2 expression showed EMT-like features associated with enhanced migration and invasiveness in vitro, and tumor growth and metastasis in vivo. The study elegantly unraveled the molecular mechanism activated by the loss of NDRG2 expression, leading to the up-regulation of MMP-19, which, in turn, directly promoted the expression of Slug at the transcriptional level, ultimately responsible for EMT-like changes. Furthermore, MMP-19-induced Slug increased the expression of a receptor tyrosine kinase, Axl, which maintained Slug expression through a positive feedback loop, and stabilized EMT of GBC cells. Altogether, these findings unveil a novel role for MMPs, acting as EMT inducing transcriptional regulators [88]. 


\subsection{Disease Mechanisms Inducting the "Transitional" Phenotype}

Multiple disease mechanisms underlying CCA carcinogenesis and progression have been associated with EMT. Ability of chronic inflammation to induce EMT changes relies on the effects of cytokines, chemokines, and growth factors widely released in the portal tract by inflammatory cells (neutrophils, lymphocytes, macrophages, myofibroblasts) in many cholangiopathies (i.e., primary biliary cirrhosis, primary sclerosing cholangitis, congenital hepatic fibrosis), as previously outlined. Furthermore, some etiologic agents may induce EMT because of their intrinsic liver damaging activity. For example, the chronic hepatitis $\mathrm{C}$ virus (HCV) infection is an established risk factor for CCA [1]. In human CCA specimens, the positive expression of the $\mathrm{HCV}$ core protein $(\mathrm{HCV})$ associated not only with lymph node metastasis, but also with EMT features (increased expression of vimentin, fibronectin and $N$-cadherin, and decreased expression of E-cadherin). Consistently, HCVc promoted "transitional" changes in cultured CCA cells, including enhanced motility and invasion, by increasing the expression and/or activity of lysyl oxidase-like 2, which prevented Snail degradation [89,90].

Autophagy is emerging as a key regulator of cell invasion in a number of human cancers, triggered by various stimuli, such as nutrient deprivation and hypoxia [91,92]. A recent study showed that starvation-induced autophagy enhanced the invasive properties of CCA cells, and, in parallel, autophagy inhibition by chloroquine significantly abrogated the TGF- $\beta 1$-induced cell invasion, thus arguing for a possible autophagy-dependent EMT regulation in CCA. Indeed, in human CCA specimens, the expression of the autophagy-related protein activating molecule in Beclin1-regulated autophagy positively correlated with the expression of Snail as well as with lymph node metastasis [93].

\section{EMT and CAFs Generation: Insights from CCA}

In addition to supporting the pro-invasive functions of tumoral epithelial cells, EMT has been claimed as a potential ancillary mechanism generating CAFs, which would represent a full mesenchymal switch [8,94]. To address this specific issue, we developed an in vivo xenograft model of CCA enabling us to trace the fate of cancer cells by a dual tracking system. An enhanced green fluorescent protein (EGFP)-expressing human male CCA cell line (EGI-1) displaying an EMT phenotype was xenografted by intraportal injection into a severe combined immune deficiency (SCID) male mouse, and dual immunofluorescence for EGFP (CCA cell marker) and $\alpha$-SMA (CAF marker) was performed on liver tumors. In this model, cancer cells undergoing a complete EMT would be expected to co-express both markers. However, although engrafted tumors faithfully reproduced the native CCA characteristics, as shown by the abundant TRS surrounding the EGFP-positive, EGI-1-derived bulk, coincident labeling between EGFP and $\alpha$-SMA was never observed. Moreover, a FISH analysis revealed that the human $Y$ chromosome specific probe was not expressed by $\alpha$-SMA-positive cells (which on the contrary, expressed the murine $Y$ chromosome), but only by EGFP-positive CCA cells. In accordance with these data, human CCA sections did not display co-expression of the cholangiocyte lineage marker K7 and $\alpha$-SMA. Taken together, these data strongly argue that in CCA, CAFs are not generated through an EMT of cancer cells, in vivo [39].

\section{CCA as Model to Redefine the Concept of EMT in Cancer Invasiveness}

Many studies suggested that EMT plays a crucial role in promoting epithelial cancer invasiveness, based on the concept that several EMT features are coherent with an invasive phenotype, and indeed, they can be reproduced by in vitro experiments. However, in CCA, a complete transition of epithelial cancer cells toward a mesenchymal phenotype is not found in vivo [39]. All the well-recognized mesenchymal features commonly displayed by neoplastic cholangiocytes, although strongly involved in CCA dissemination, are more consistent with the concept of "transitional" changes leading to an invasive phenotype, but developing in the context of a preserved native epithelial identity [46]. The general assumption that the gain or loss of expression of one or more molecules typically serving as lineage biomarkers necessarily reflects a large-scale gene expression reprogramming is appealing, but 
questionable. In CCA, the presence of a "transitional" phenotype may instead represent the synergic effect between an ongoing tumoral dedifferentiation process, regulated by stochastic mutational events, and the influence of paracrine signals originating from the TRS $[9,95,96]$. When the resulting changes in gene expression are such that cancer cells gain a more malignant phenotype endowed with pro-invasive features, those cells would then likely become overrepresented through a process of Darwinian selection [5]. However, these phenotypic dynamics are markedly different from the finely-regulated lineage conversion program typically occurring in embryonic cells undergoing EMT during organogenesis.

It is worth underlining that a highly malignant behavior associated with EMT by several studies is that of the cancer stem cell (CSC) endowed with unlimited self-renewal capabilities, heightened resistance to apoptosis and strong chemoresistance [97]. Shuang et al. [98] reported that TGF- $\beta 1$-induced EMT provides CCA cells with a range of stem cell-like features, including expression of pluripotency transcription factors (Sox2 and Oct3/4) and enhanced resistance to chemotherapeutic drugs. Consistently, CCA cells constitutionally expressing the CSC biomarker aldehyde dehydrogenase $(\mathrm{ALDH})$, showed reduced E-cadherin expression, and increased expression of vimentin, fibronectin and $\mathrm{N}$-cadherin, compared with ALDH-negative cells [98]. This intimate link between EMT and stemness may be a pivotal factor promoting metastatic colonization. Indeed, the concept that only metastasizing cells endowed with self-renewal capabilities are responsible for ectopic tumor dissemination [5] is emerging. Interestingly, co-expression of stem cell and EMT properties has also been reported in cell populations isolated from early human fetal liver [99], suggesting that the "transitional" changes undergone by neoplastic cholangiocytes may overall represent an aberrant reactivation of an embryonic behavior.

\section{Conclusions}

The aggressiveness of CCA is associated with the expression by neoplastic ducts of "transitional" / pro-invasive features, some of which have also a strong prognostic value. These are the result of paracrine signals originating from the stromal compartment, which closely accompanies the growth of tumoral ducts, acting in concert with signaling perturbations arising in the cancer cells themselves (Figure 1). However, these phenotypic changes do not reflect a full conversion of CCA cells towards a mesenchymal phenotype, which potentially would lead to the generation of the reactive stroma, a feature particularly abundant in CCA. Nonetheless, the gain of EMT-like features by neoplastic cholangiocytes may have profound implications for the management of CCA patients, by identifying biomarkers serving as prognostic factors and/or predictors of treatment response, as it is the case with nuclear S100A4, and by providing novel molecular therapeutic targets. Notably, some EMT-interfering agents, such as inhibitors of TGF- $\beta$ signaling, TGF- $\beta$ type I receptor, and EGF receptor, have been recently tested in clinical trials in patients with carcinomas with promising effects [100]. 


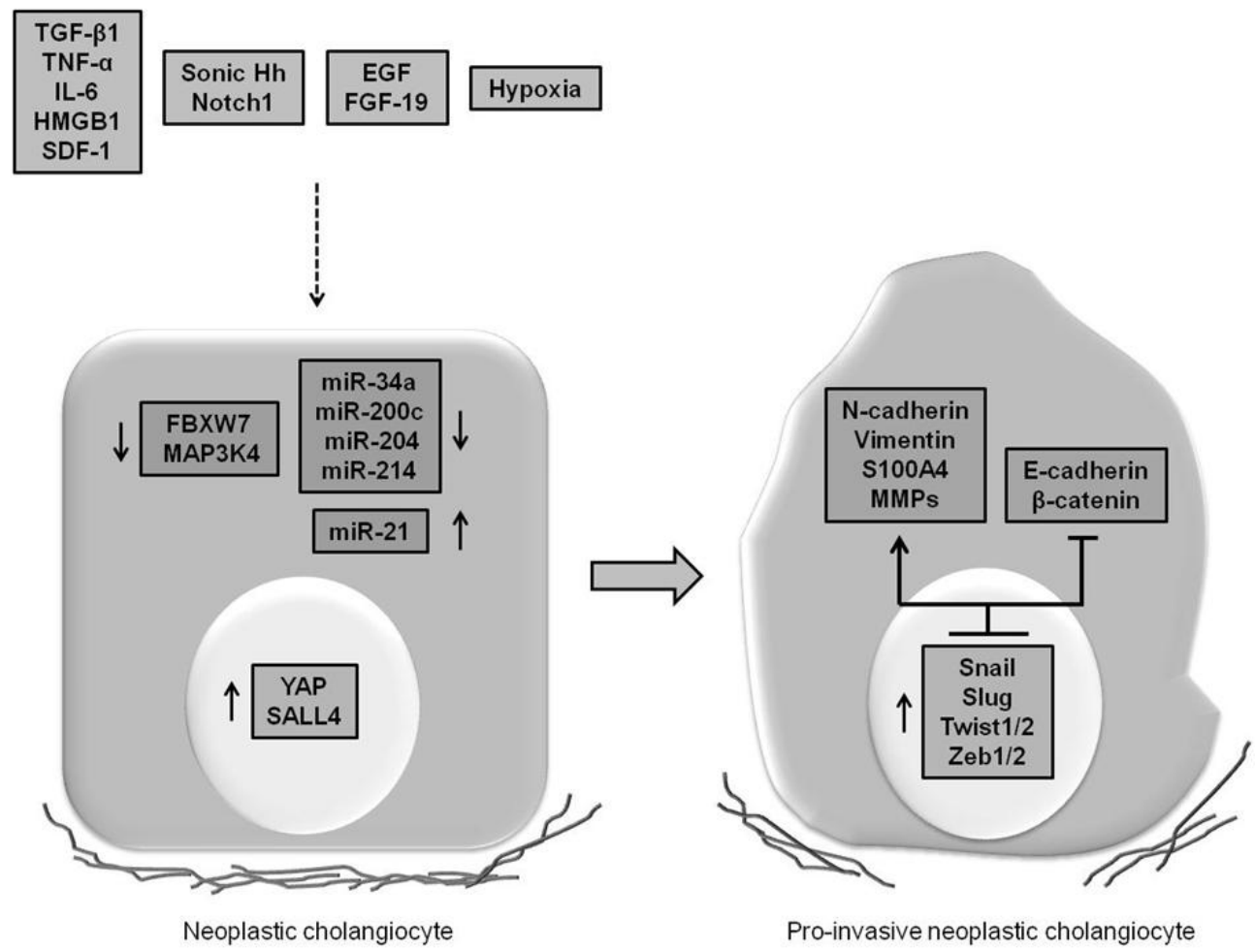

Figure 1. Autocrine and paracrine signals and intracellular stimuli orchestrate the switch towards a "transitional" phenotype during neoplastic transformation. The emergence of mesenchymal traits in CCA cells (up-regulation of $N$-cadherin, vimentin, S100A4 and metalloproteinases, along with down-regulation of E-cadherin and membranous $\beta$-catenin) is driven by a set of embryonic transcription factors (Snail, Slug, Twist1/2, and Zeb1/2), whose expression is induced by both soluble factors released in the tumor microenvironment (cyto/chemokines, growth factors, and morphogens) and mutational events affecting the activity of miRNAs, oncogenes, and tumor suppressor genes. These "transitional" changes allow cancer cells to reduce intercellular adhesion and dismantle the basement membrane, resulting in a motile phenotype. Transforming growth factor $\beta 1$, TGF- $\beta 1$; tumor necrosis factor $\alpha$, TNF- $\alpha$; interleukin 6, IL-6; high-mobility group box 1, HMGB1; stromal cell-derived factor 1, SDF-1; epidermal growth factor, EGF; fibroblast growth factor 19, FGF-19; Hedgehog, Hh; F-box and WD repeat domain-containing 7, FBXW7; mitogen-activated protein 3 kinase 4, MAP3K4; yes-associated protein, YAP; spalt-like transcription factor 4, SALL4; metalloproteinase, MMP.

Acknowledgments: NIH Grant DK079005, Silvio O. Conte Digestive Diseases Research Core Centers-5P30DK034989", grant from "PSC partners for a care", projects CARIPLO 2011-0470 and PRIN 2009ARYX4T_005 to MS. Progetto di Ricerca Ateneo 2011 (grant \#CPD113799/11) to Luca Fabris and Massimiliano Cadamuro. Associazione Scientifica Gastroenterologica di Treviso (ASGET, “associazione di promozione sociale senza scopo di lucro") to Luca Fabris.

Conflicts of Interest: The authors declare no conflict of interest.

\section{References}

1. Gatto, M.; Bragazzi, M.C.; Semeraro, R.; Napoli, C.; Gentile, R.; Torrice, A.; Gaudio, E.; Alvaro, D. Cholangiocarcinoma: Update and future perspectives. Dig. Liver Dis. 2010, 42, 253-260. [CrossRef] [PubMed]

2. Khan, S.A.; Davidson, B.R.; Goldin, R.D.; Heaton, N.; Karani, J.; Pereira, S.P.; Rosenberg, W.M.; Tait, P.; Taylor-Robinson, S.D.; Thillainayagam, A.V.; et al. Guidelines for the diagnosis and treatment of cholangiocarcinoma: An update. Gut 2012, 61, 1657-1669. [CrossRef] [PubMed]

3. Fabris, L.; Alvaro, D. The prognosis of perihilar cholangiocarcinoma after radical treatments. Hepatology 2012, 56, 800-802. [CrossRef] [PubMed] 
4. Zabron, A.; Edwards, R.J.; Khan, S.A. The challenge of cholangiocarcinoma: Dissecting the molecular mechanisms of an insidious cancer. Dis. Model. Mech. 2013, 6, 281-292. [CrossRef] [PubMed]

5. Valastyan, S.; Weinberg, R.A. Tumor metastasis: Molecular insights and evolving paradigms. Cell 2011, 147, 275-292. [CrossRef] [PubMed]

6. Clark, A.G.; Vignjevic, D.M. Modes of cancer cell invasion and the role of the microenvironment. Curr. Opin. Cell Biol. 2015, 36, 13-22. [CrossRef] [PubMed]

7. Fabris, L.; Cadamuro, M.; Moserle, L.; Dziura, J.; Cong, X.; Sambado, L.; Nardo, G.; Sonzogni, A.; Colledan, M.; Furlanetto, A.; et al. Nuclear expression of S100A4 calcium-binding protein increases cholangiocarcinoma invasiveness and metastatisation. Hepatology 2011, 54, 890-899. [CrossRef] [PubMed]

8. Hanahan, D.; Weinberg, R.A. Hallmarks of cancer: The next generation. Cell 2011, 144, 646-674. [CrossRef] [PubMed]

9. Thiery, J.P.; Acloque, H.; Huang, R.Y.; Nieto, M.A. Epithelial-mesenchymal transitions in development and disease. Cell 2009, 139, 871-890. [CrossRef] [PubMed]

10. Gurzu, S.; Turdean, S.; Kovecsi, A.; Contac, A.O.; Jung, I. Epithelial-mesenchymal, mesenchymal-epithelial, and endothelial-mesenchymal transitions in malignant tumors: An update. World J. Clin. Cases 2015, 3, 393-404. [CrossRef] [PubMed]

11. Acloque, H.; Adams, M.S.; Fishwick, K.; Bronner-Fraser, M.; Nieto, M.A. Epithelial-mesenchymal transitions: The importance of changing cell state in development and disease. J. Clin. Investig. 2009, 119, 1438-1449. [CrossRef] [PubMed]

12. Fabris, L.; Strazzabosco, M. Epithelial-mesenchymal interactions in biliary diseases. Semin. Liver Dis. 2011, 31, 11-32. [CrossRef] [PubMed]

13. Huang, R.Y.; Guilford, P.; Thiery, J.P. Early events in cell adhesion and polarity during epithelial-mesenchymal transition. J. Cell Sci. 2012, 125, 4417-4422. [CrossRef] [PubMed]

14. Lamouille, S.; Xu, J.; Derynck, R. Molecular mechanisms of epithelial-mesenchymal transition. Nat. Rev. Mol. Cell Biol. 2014, 15, 178-196. [CrossRef] [PubMed]

15. Katsuno, Y.; Lamouille, S.; Derynck, R. TGF- $\beta$ signaling and epithelial-mesenchymal transition in cancer progression. Curr. Opin. Oncol. 2013, 25, 76-84. [CrossRef] [PubMed]

16. Gonzalez, D.M.; Medici, D. Signaling mechanisms of the epithelial-mesenchymal transition. Sci. Signal. 2014, 7. [CrossRef] [PubMed]

17. Guo, F.; Parker Kerrigan, B.C.; Yang, D.; Hu, L.; Shmulevich, I.; Sood, A.K.; Xue, F.; Zhang, W. Post-transcriptional regulatory network of epithelial-to-mesenchymal and mesenchymal-to-epithelial transitions. J. Hematol. Oncol. 2014, 7, 19. [CrossRef] [PubMed]

18. Lindsey, S.; Langhans, S.A. Crosstalk of Oncogenic Signaling Pathways during Epithelial-Mesenchymal Transition. Front. Oncol. 2014, 4, 358. [CrossRef] [PubMed]

19. Li, J.; Yang, B.; Zhou, Q.; Wu, Y.; Shang, D.; Guo, Y.; Song, Z.; Zheng, Q.; Xiong, J. Autophagy promotes hepatocellular carcinoma cell invasion through activation of epithelial-mesenchymal transition. Carcinogenesis 2013, 34, 1343-1351. [CrossRef] [PubMed]

20. Qiang, L.; He, Y.Y. Autophagy deficiency stabilizes TWIST1 to promote epithelial-mesenchymal transition. Autophagy 2014, 10, 1864-1865. [CrossRef] [PubMed]

21. Thiery, J.P. Epithelial-mesenchymal transitions in tumour progression. Nat. Rev. Cancer 2002, 2, $442-454$. [CrossRef] [PubMed]

22. Peinado, H.; Portillo, F.; Cano, A. Transcriptional regulation of cadherins during development and carcinogenesis. Int. J. Dev. Biol. 2004, 48, 365-375. [CrossRef] [PubMed]

23. Lee, J.M.; Dedhar, S.; Kalluri, R.; Thompson, E.W. The epithelial-mesenchymal transition: New insights in signaling, development, and disease. J. Cell Biol. 2006, 172, 973-981. [CrossRef] [PubMed]

24. Raimondi, C.; Gradilone, A.; Naso, G.; Vincenzi, B.; Petracca, A.; Nicolazzo, C.; Palazzo, A.; Saltarelli, R.; Spremberg, F.; Cortesi, E.; et al. Epithelial-mesenchymal transition and stemness features in circulating tumor cells from breast cancer patients. Breast Cancer Res. Treat. 2011, 130, 449-455. [CrossRef] [PubMed]

25. Gradilone, A.; Raimondi, C.; Nicolazzo, C.; Petracca, A.; Gandini, O.; Vincenzi, B.; Naso, G.; Aglianò, A.M.; Cortesi, E.; Gazzaniga, P. Circulating tumour cells lacking cytokeratin in breast cancer: The importance of being mesenchymal. J. Cell Mol. Med. 2011, 15, 1066-1070. [CrossRef] [PubMed] 
26. Sarrió, D.; Rodriguez-Pinilla, S.M.; Hardisson, D.; Cano, A.; Moreno-Bueno, G.; Palacios, J. Epithelial-mesenchymal transition in breast cancer relates to the basal-like phenotype. Cancer Res. 2008, 68, 989-997. [CrossRef] [PubMed]

27. Liu, T.; Zhang, X.; Shang, M.; Zhang, Y.; Xia, B.; Niu, M.; Liu, Y.; Pang, D. Dysregulated expression of Slug, vimentin, and E-cadherin correlates with poor clinical outcome in patients with basal-like breast cancer. J. Surg. Oncol. 2013, 107, 188-194. [CrossRef] [PubMed]

28. Yamada, S.; Fuchs, B.C.; Fujii, T.; Shimoyama, Y.; Sugimoto, H.; Nomoto, S.; Takeda, S.; Tanabe, K.K.; Kodera, Y.; Nakao, A. Epithelial-to-mesenchymal transition predicts prognosis of pancreatic cancer. Surgery 2013, 154, 946-954. [CrossRef] [PubMed]

29. Murai, T.; Yamada, S.; Fuchs, B.C.; Fujii, T.; Nakayama, G.; Sugimoto, H.; Koike, M.; Fujiwara, M.; Tanabe, K.K.; Kodera, Y. Epithelial-to-mesenchymal transition predicts prognosis in clinical gastric cancer. J. Surg. Oncol. 2014, 109, 684-689. [CrossRef] [PubMed]

30. Fan, X.J.; Wan, X.B.; Yang, Z.L.; Fu, X.H.; Huang, Y.; Chen, D.K.; Song, S.X.; Liu, Q.; Xiao, H.Y.; Wang, L.; Wang, J.P. Snail promotes lymph node metastasis and Twist enhances tumor deposit formation through epithelial-mesenchymal transition in colorectal cancer. Hum. Pathol. 2013, 44, 173-180. [CrossRef] [PubMed]

31. Shi, Y.; Wu, H.; Zhang, M.; Ding, L.; Meng, F.; Fan, X. Expression of the epithelial-mesenchymal transition-related proteins and their clinical significance in lung adenocarcinoma. Diagn. Pathol. 2013, 8, 89. [CrossRef] [PubMed]

32. Zhang, H.J.; Wang, H.Y.; Zhang, H.T.; Su, J.M.; Zhu, J.; Wang, H.B.; Zhou, W.Y.; Zhang, H.; Zhao, M.C.; Zhang, L.; et al. Transforming growth factor- $\beta 1$ promotes lung adenocarcinoma invasion and metastasis by epithelial-to-mesenchymal transition. Mol. Cell Biochem. 2011, 355, 309-314. [CrossRef] [PubMed]

33. Cho, H.J.; Park, S.M.; Kim, I.K.; Nam, I.K.; Baek, K.E.; Im, M.J.; Yoo, J.M.; Park, S.H.; Ryu, K.J.; Han, H.T.; et al. RhoGDI2 promotes epithelial-mesenchymal transition via induction of Snail in gastric cancer cells. Oncotarget 2014, 5, 1554-1564. [CrossRef] [PubMed]

34. Wang, H.; Zhang, G.; Zhang, H.; Zhang, F.; Zhou, B.; Ning, F.; Wang, H.S.; Cai, S.H.; Du, J. Acquisition of epithelial-mesenchymal transition phenotype and cancer stem cell-like properties in cisplatin-resistant lung cancer cells through AKT/ $\beta$-catenin/Snail signaling pathway. Eur. J. Pharmacol. 2014, 723, 156-166. [CrossRef] [PubMed]

35. Wang, W.S.; Yang, X.S.; Xia, M.; Jiang, H.Y.; Hou, J.Q. Silencing of twist expression by RNA interference suppresses epithelial-mesenchymal transition, invasion, and metastasis of ovarian cancer. Asian Pac. J. Cancer Prev. 2012, 13, 4435-4439. [CrossRef] [PubMed]

36. Bandyopadhyay, A.; Agyin, J.K.; Wang, L.; Jiang, H.Y.; Hou, J.Q. Inhibition of pulmonary and skeletal metastasis by a transforming growth factor- $\beta$ type I receptor kinase inhibitor. Cancer Res. 2006, 66, 6714-6721. [CrossRef] [PubMed]

37. Nishioka, R.; Itoh, S.; Gui, T.; Gai, Z.; Oikawa, K.; Kawai, M.; Tani, M.; Yamaue, H.; Muragaki, Y. SNAIL induces epithelial-to-mesenchymal transition in a human pancreatic cancer cell line (BxPC3) and promotes distant metastasis and invasiveness in vivo. Exp. Mol. Pathol. 2010, 89, 149-157. [CrossRef] [PubMed]

38. Yang, J.; Mani, S.A.; Donaher, J.L.; Ramaswamy, S.; Itzykson, R.A.; Come, C.; Savagner, P.; Gitelman, I.; Richardson, A.; Weinberg, R.A. Twist, a master regulator of morphogenesis, plays an essential role in tumor metastasis. Cell 2004, 117, 927-939. [CrossRef] [PubMed]

39. Cadamuro, M.; Nardo, G.; Indraccolo, S.; Dall'olmo, L.; Sambado, L.; Moserle, L.; Franceschet, I.; Colledan, M.; Massani, M.; Stecca, T.; et al. Platelet-derived growth factor-D and Rho GTPases regulate recruitment of cancer-associated fibroblasts in cholangiocarcinoma. Hepatology 2013, 58, 1042-1053. [CrossRef] [PubMed]

40. Yao, X.; Wang, X.; Wang, Z.; Dai, L.; Zhang, G.; Yan, Q.; Zhou, W. Clinicopathological and prognostic significance of epithelial mesenchymal transition-related protein expression in intrahepatic cholangiocarcinoma. Onco. Targets Ther. 2012, 5, 255-261. [CrossRef] [PubMed]

41. Nitta, T.; Mitsuhashi, T.; Hatanaka, Y.; Miyamoto, M.; Oba, K.; Tsuchikawa, T.; Suzuki, Y.; Hatanaka, K.C.; Hirano, S.; Matsuno, Y. Prognostic significance of epithelial-mesenchymal transition-related markers in extrahepatic cholangiocarcinoma: Comprehensive immunohistochemical study using a tissue microarray. Br. J. Cancer 2014, 111, 1363-1372. [CrossRef] [PubMed]

42. Huang, X.Y.; Zhang, C.; Cai, J.B.; Shi, G.M.; Ke, A.W.; Dong, Z.R.; Zhang, P.F.; Fan, J.; Peng, B.G.; Zhou, J. Comprehensive multiple molecular profile of epithelial mesenchymal transition in intrahepatic cholangiocarcinoma patients. PLoS ONE 2014, 9, e96860. [CrossRef] [PubMed] 
43. Gu, M.J.; Choi, J.H. Epithelial-mesenchymal transition phenotypes are associated with patient survival in intrahepatic cholangiocarcinoma. J. Clin. Pathol. 2014, 67, 229-234. [CrossRef] [PubMed]

44. Techasen, A.; Loilome, W.; Namwat, N.; Khuntikeo, N.; Puapairoj, A.; Jearanaikoon, P.; Saya, H.; Yongvanit, P. Loss of E-cadherin promotes migration and invasion of cholangiocarcinoma cells and serves as a potential marker of metastasis. Tumour. Biol. 2014, 35, 8645-8652. [CrossRef] [PubMed]

45. Fabris, L.; Cadamuro, M.; Sambado, L.; Beretta, I.; Spirli, C.; Indraccolo, S.; Strazzabosco, M. Selective reduction in S100A4 nuclear expression by low-dose paclitaxel halts invasiveness of human cholangiocarcinoma cells through a RHO-A/CDC42-dependent mechanism [abstract]. In Proceedings of the AASLD 63rd Annual Meeting, Boston, MA, USA, 9-13 November 2012.

46. Cadamuro, M.; Morton, S.D.; Strazzabosco, M.; Fabris, L. Unveiling the role of tumor reactive stroma in cholangiocarcinoma: An opportunity for new therapeutic strategies. Transl. Gastrointest. Cancer 2013, 2, 130-144.

47. Cirri, P.; Chiarugi, P. Cancer associated fibroblasts: The dark side of the coin. Am. J. Cancer Res. 2011, 1, 482-497. [PubMed]

48. Techasen, A.; Loilome, W.; Namwat, N.; Dokduang, H.; Jongthawin, J.; Yongvanit, P. Cytokines released from activated human macrophages induce epithelial mesenchymal transition markers of cholangiocarcinoma cells. Asian Pac. J. Cancer Prev. 2012, 13, 115-118. [PubMed]

49. Thanee, M.; Loilome, W.; Techasen, A.; Namwat, N.; Boonmars, T.; Pairojkul, C.; Yongvanit, P. Quantitative changes in tumor-associated M2 macrophages characterize cholangiocarcinoma and their association with metastasis. Asian Pac. J. Cancer Prev. 2015, 16, 3043-3050. [CrossRef] [PubMed]

50. Okamoto, K.; Tajima, H.; Nakanuma, S.; Sakai, S.; Makino, I.; Kinoshita, J.; Hayashi, H.; Nakamura, K.; Oyama, K.; Nakagawara, H.; et al. Angiotensin II enhances epithelial-to-mesenchymal transition through the interaction between activated hepatic stellate cells and the stromal cell-derived factor-1/CXCR4 axis in intrahepatic cholangiocarcinoma. Int. J. Oncol. 2012, 41, 573-582. [CrossRef] [PubMed]

51. Yu, Y.; Xiao, C.H.; Tan, L.D.; Wang, Q.S.; Li, X.Q.; Feng, Y.M. Cancer-associated fibroblasts induce epithelial-mesenchymal transition of breast cancer cells through paracrine TGF- $\beta$ signalling. Br. J. Cancer 2014, 110, 724-732. [CrossRef] [PubMed]

52. Liu, R.; Li, J.; Xie, K.; Zhang, T.; Lei, Y.; Chen, Y.; Zhang, L.; Huang, K.; Wang, K.; Wu, H.; et al. FGFR4 promotes stroma-induced epithelial-to-mesenchymal transition in colorectal cancer. Cancer Res. 2013, 73, 5926-5935. [CrossRef] [PubMed]

53. Sirica, A.E.; Campbell, D.J.; Dumur, C.I. Cancer-associated fibroblasts in intrahepatic cholangiocarcinoma. Curr. Opin. Gastroenterol. 2011, 27, 276-284. [CrossRef] [PubMed]

54. Zhou, C.; Zheng, Y.; Li, L.; Zhai, W.; Li, R.; Liang, Z.; Zhao, L. Adrenomedullin promotes intrahepatic cholangiocellular carcinoma metastasis and invasion by inducing epithelial-mesenchymal transition. Oncol. Rep. 2015, 34, 610-616. [CrossRef] [PubMed]

55. Sato, Y.; Harada, K.; Itatsu, K.; Ikeda, H.; Kakuda, Y.; Shimomura, S.; Shan Ren, X.; Yoneda, N.; Sasaki, M.; Nakanuma, Y. Epithelial-mesenchymal transition induced by transforming growth factor- $\beta 1 /$ Snail activation aggravates invasive growth of cholangiocarcinoma. Am. J. Pathol. 2010, 177, 141-152. [CrossRef] [PubMed]

56. Araki, K.; Shimura, T.; Suzuki, H.; Tsutsumi, S.; Wada, W.; Yajima, T.; Kobayahi, T.; Kubo, N.; Kuwano, H. E/N-cadherin switch mediates cancer progression via TGF- $\beta$-induced epithelial-to-mesenchymal transition in extrahepatic cholangiocarcinoma. Br. J. Cancer 2011, 105, 1885-1893. [CrossRef] [PubMed]

57. Hirose, A.; Tajima, H.; Ohta, T.; Tsukada, T.; Okamoto, K.; Nakanuma, S.; Sakai, S.; Kinoshita, J.; Makino, I.; Furukawa, H.; et al. Low-dose paclitaxel inhibits the induction of epidermal-mesenchymal transition in the human cholangiocarcinoma CCKS-1 cell line. Oncol. Lett. 2013, 6, 915-920. [PubMed]

58. Duangkumpha, K.; Techasen, A.; Loilome, W.; Namwat, N.; Thanan, R.; Khuntikeo, N.; Yongvanit, P. BMP-7 blocks the effects of TGF- $\beta$-induced EMT in cholangiocarcinoma. Tumour. Biol. 2014, 35, 9667-9676. [CrossRef] [PubMed]

59. Techasen, A.; Namwat, N.; Loilome, W.; Bungkanjana, P.; Khuntikeo, N.; Puapairoj, A.; Jearanaikoon, P.; Saya, H.; Yongvanit, P. Tumor necrosis factor- $\alpha$ (TNF- $\alpha)$ stimulates the epithelial-mesenchymal transition regulator Snail in cholangiocarcinoma. Med. Oncol. 2012, 29, 3083-3091. [CrossRef] [PubMed]

60. Zhou, Q.X.; Jiang, X.M.; Wang, Z.D.; Li, C.L.; Cui, Y.F. Enhanced expression of suppresser of cytokine signaling 3 inhibits the IL-6-induced epithelial-to-mesenchymal transition and cholangiocarcinoma cell metastasis. Med. Oncol. 2015, 32, 105. [CrossRef] [PubMed] 
61. Xu, Y.F.; Ge, F.J.; Han, B.; Yang, X.Q.; Su, H.; Zhao, A.C.; Zhao, M.H.; Yang, Y.B.; Yang, J. High-mobility group box 1 expression and lymph node metastasis in intrahepatic cholangiocarcinoma. World J. Gastroenterol. 2015, 21, 3256-3265. [PubMed]

62. Lee, M.J.; Yu, G.R.; Yoo, H.J.; Kim, J.H.; Yoon, B.I.; Choi, Y.K.; Kim, D.G. ANXA8 down-regulation by EGF-FOXO4 signaling is involved in cell scattering and tumor metastasis of cholangiocarcinoma. Gastroenterology 2009, 137, 1138-1150. [CrossRef] [PubMed]

63. Clapéron, A.; Mergey, M.; Nguyen Ho-Bouldoires, T.H.; Vignjevic, D.; Wendum, D.; Chrétien, Y.; Merabtene, F.; Frazao, A.; Paradis, V.; et al. EGF/EGFR axis contributes to the progression of cholangiocarcinoma through the induction of an epithelial-mesenchymal transition. J. Hepatol. 2014, 61, 325-332. [CrossRef] [PubMed]

64. Xu, Y.F.; Yang, X.Q.; Lu, X.F.; Guo, S.; Liu, Y.; Iqbal, M.; Ning, S.L.; Yang, H.; Suo, N.; Chen, Y.X. Fibroblast growth factor receptor 4 promotes progression and correlates to poor prognosis in cholangiocarcinoma. Biochem. Biophys. Res. Commun. 2014, 446, 54-60. [CrossRef] [PubMed]

65. El Khatib, M.; Bozko, P.; Palagani, V.; Malek, N.P.; Wilkens, L.; Plentz, R.R. Activation of Notch signaling is required for cholangiocarcinoma progression and is enhanced by inactivation of p53 in vivo. PLoS ONE 2013, 8, e77433. [CrossRef] [PubMed]

66. Zhou, Q.; Wang, Y.; Peng, B.; Liang, L.; Li, J. The roles of Notch1 expression in the migration of intrahepatic cholangiocarcinoma. BMC Cancer 2013, 13, 244. [CrossRef] [PubMed]

67. Matsushima, H.; Kuroki, T.; Kitasato, A.; Adachi, T.; Tanaka, T.; Hirabaru, M.; Hirayama, T.; Kuroshima, N.; Hidaka, M.; Soyama, A.; et al. Sox9 expression in carcinogenesis and its clinical significance in intrahepatic cholangiocarcinoma. Dig. Liver Dis. 2015. [CrossRef] [PubMed]

68. El Khatib, M.; Kalnytska, A.; Palagani, V.; Kossatz, U.; Manns, M.P.; Malek, N.P.; Wilkens, L.; Plentz, R.R. Inhibition of hedgehog signaling attenuates carcinogenesis in vitro and increases necrosis of cholangiocellular carcinoma. Hepatology 2013, 57, 1035-1045. [CrossRef] [PubMed]

69. Kiesslich, T.; Pichler, M.; Neureiter, D. Epigenetic control of epithelial-mesenchymal-transition in human cancer. Mol. Clin. Oncol. 2013, 1, 3-11. [PubMed]

70. Peinado, H.; Ballestar, E.; Esteller, M.; Cano, A. Snail mediates E-cadherin repression by the recruitment of the Sin3A/histone deacetylase 1 (HDAC1)/HDAC2 complex. Mol. Cell Biol. 2004, 24, 306-319. [CrossRef] [PubMed]

71. Lim, S.O.; Gu, J.M.; Kim, M.S.; Kim, H.S.; Park, Y.N.; Park, C.K.; Cho, J.W.; Park, Y.M.; Jung, G. Epigenetic changes induced by reactive oxygen species in hepatocellular carcinoma: Methylation of the E-cadherin promoter. Gastroenterology 2008, 135, 2128-2140. [CrossRef] [PubMed]

72. Kurashige, J.; Mima, K.; Sawada, G.; Takahashi, Y.; Eguchi, H.; Sugimachi, K.; Mori, M.; Yanagihara, K.; Yashiro, M.; Hirakawa, K.; et al. Epigenetic modulation and repression of miR-200b by cancer-associated fibroblasts contribute to cancer invasion and peritoneal dissemination in gastric cancer. Carcinogenesis 2015, 36, 133-141. [CrossRef] [PubMed]

73. Xu, L.; Deng, Q.; Pan, Y.; Peng, M.; Wang, X.; Song, L.; Xiao, M.; Wang, Z. Cancer-associated fibroblasts enhance the migration ability of ovarian cancer cells by increasing EZH2 expression. Int. J. Mol. Med. 2014, 33, 91-96. [PubMed]

74. Lin, H.J.; Zuo, T.; Lin, C.H.; Kuo, C.T.; Liyanarachchi, S.; Sun, S.; Shen, R.; Deatherage, D.E.; Potter, D.; Asamoto, L.; et al. Breast cancer-associated fibroblasts confer AKT1-mediated epigenetic silencing of Cystatin $\mathrm{M}$ in epithelial cells. Cancer Res. 2008, 68, 10257-10266. [CrossRef] [PubMed]

75. Zhang, B.; Pan, X.; Cobb, G.P.; Anderson, T.A. microRNAs as oncogenes and tumor suppressors. Dev. Biol. 2007, 302. [CrossRef] [PubMed]

76. Munoz-Garrido, P.; García-Fernández de Barrena, M.; Hijona, E.; Carracedo, M.; Marín, J.J.; Bujanda, L.; Banales, J.M. MicroRNAs in biliary diseases. World J. Gastroenterol. 2012, 18, 6189-6196. [CrossRef] [PubMed]

77. Piontek, K.; Selaru, F.M. MicroRNAs in the biology and diagnosis of cholangiocarcinoma. Semin. Liver Dis. 2015, 35, 55-62. [CrossRef] [PubMed]

78. Liu, Z.; Jin, Z.Y.; Liu, C.H.; Xie, F.; Lin, X.S.; Huang, Q. microRNA-21 regulates biological behavior by inducing EMT in human cholangiocarcinoma. Int. J. Clin. Exp. Pathol. 2015, 8, 4684-4694. [PubMed]

79. Li, B.; Han, Q.; Zhu, Y.; Yu, Y.; Wang, J.; Jiang, X. Down-regulation of miR-214 contributes to intrahepatic cholangiocarcinoma metastasis by targeting Twist. FEBS J. 2012, 279, 2393-2398. [CrossRef] [PubMed] 
80. Qiu, Y.H.; Wei, Y.P.; Shen, N.J.; Wang, Z.C.; Kan, T.; Yu, W.L.; Yi, B.; Zhang, Y.J. miR-204 inhibits epithelial to mesenchymal transition by targeting slug in intrahepatic cholangiocarcinoma cells. Cell Physiol. Biochem. 2013, 32, 1331-1341. [CrossRef] [PubMed]

81. Oishi, N.; Kumar, M.R.; Roessler, S.; Ji, J.; Forgues, M.; Budhu, A.; Zhao, X.; Andersen, J.B.; Ye, Q.H.; Jia, H.L.; et al. Transcriptomic profiling reveals hepatic stem-like gene signatures and interplay of miR-200c and epithelial-mesenchymal transition in intrahepatic cholangiocarcinoma. Hepatology 2012, 56, 1792-1803. [CrossRef] [PubMed]

82. Qiao, P.; Li, G.; Bi, W.; Yang, L.; Yao, L.; Wu, D. microRNA-34a inhibits epithelial mesenchymal transition in human cholangiocarcinoma by targeting Smad4 through transforming growth factor- $\beta /$ Smad pathway. BMC Cancer 2015, 15, 469. [CrossRef] [PubMed]

83. Deng, G.; Zhu, L.; Huang, F.; Nie, W.; Huang, W.; Xu, H.; Zheng, S.; Yi, Z.; Wan, T. SALL4 is a novel therapeutic target in intrahepatic cholangiocarcinoma. Oncotarget 2015, 6, 27416-27426. [CrossRef] [PubMed]

84. Pei, T.; Li, Y.; Wang, J.; Wang, H.; Liang, Y.; Shi, H.; Sun, B.; Yin, D.; Sun, J.; Song, R.; et al. YAP is a critical oncogene in human cholangiocarcinoma. Oncotarget 2015, 6, 17206-17220. [CrossRef] [PubMed]

85. Yang, J.; Chai, L.; Fowles, T.C.; Alipio, Z.; Xu, D.; Fink, L.M.; Ward, D.C.; Ma, Y. Genome-wide analysis reveals Sall4 to be a major regulator of pluripotency in murine-embryonic stem cells. Proc. Natl. Acad. Sci. USA 2008, 105, 19756-19761. [CrossRef] [PubMed]

86. Yang, H.; Lu, X.; Liu, Z.; Chen, L.; Xu, Y.; Wang, Y.; Wei, G.; Chen, Y. FBXW7 suppresses epithelial-mesenchymal transition, stemness and metastatic potential of cholangiocarcinoma cells. Oncotarget 2015, 6, 6310-6325. [CrossRef] [PubMed]

87. Yang, L.X.; Gao, Q.; Shi, J.Y.; Wang, Z.C.; Zhang, Y.; Gao, P.T.; Wang, X.Y.; Shi, Y.H.; Ke, A.W.; Shi, G.M.; et al. Mitogen-activated protein kinase kinase kinase 4 Deficiency in Intrahepatic Cholangiocarcinoma Leads to Invasive Growth and Epithelial-Mesenchymal Transition. Hepatology 2015. [CrossRef] [PubMed]

88. Lee, D.G.; Lee, S.H.; Kim, J.S.; Park, J.; Cho, Y.L.; Kim, K.S.; Jo, D.Y.; Song, I.C.; Kim, N.; Yun, H.J.; et al. Loss of NDRG2 promotes epithelial-mesenchymal transition of gallbladder carcinoma cells through MMP-19-mediated Slug expression. J. Hepatol. 2015. [CrossRef] [PubMed]

89. Li, T.; Li, D.; Cheng, L.; Wu, H.; Gao, Z.; Liu, Z.; Jiang, W.; Gao, Y.H.; Tian, F.; Zhao, L.; et al. Epithelial-mesenchymal transition induced by hepatitis $C$ virus core protein in cholangiocarcinoma. Ann. Surg. Oncol. 2010, 17, 1937-1944. [CrossRef] [PubMed]

90. Peinado, H.; Del Carmen Iglesias-de la Cruz, M.; Olmeda, D.; Csiszar, K.; Fong, K.S.; Vega, S.; Nieto, M.A.; Cano, A.; Portillo, F. A molecular role for lysyl oxidase-like 2 enzyme in snail regulation and tumor progression. EMBO J. 2005, 24, 3446-3458. [CrossRef] [PubMed]

91. Kenific, C.M.; Debnath, J. Cellular and metabolic functions for autophagy in cancer cells. Trends Cell Biol. 2015, 25, 37-45. [CrossRef] [PubMed]

92. Thongchot, S.; Yongvanit, P.; Loilome, W.; Seubwai, W.; Phunicom, K.; Tassaneeyakul, W.; Pairojkul, C.; Promkotra, W.; Techasen, A.; Namwat, N. High expression of HIF-1 $\alpha$, BNIP3 and PI3KC3: Hypoxia-induced autophagy predicts cholangiocarcinoma survival and metastasis. Asian Pac. J. Cancer Prev. 2014, 15, 5873-5878. [CrossRef] [PubMed]

93. Nitta, T.; Sato, Y.; Ren, X.S.; Harada, K.; Sasaki, M.; Hirano, S.; Nakanuma, Y. Autophagy may promote carcinoma cell invasion and correlate with poor prognosis in cholangiocarcinoma. Int. J. Clin. Exp. Pathol. 2014, 7, 4913-4921. [PubMed]

94. Anderberg, C.; Pietras, K. On the origin of cancer-associated fibroblasts. Cell Cycle 2009, 8, 1461-1462. [CrossRef] [PubMed]

95. Tarin, D.; Thompson, E.W.; Newgreen, D.F. The fallacy of epithelial mesenchymal transition in neoplasia. Cancer Res. 2005, 65, 5996-6000. [CrossRef] [PubMed]

96. Giannelli, G. The epithelial-mesenchymal transition: Fact or fiction in cancer? Hepatology 2009, 50, $1344-1346$. [CrossRef] [PubMed]

97. May, C.D.; Sphyris, N.; Evans, K.W.; Werden, S.J.; Guo, W.; Mani, S.A. Epithelial-mesenchymal transition and cancer stem cells: A dangerously dynamic duo in breast cancer progression. Breast Cancer Res. 2011, 13, 202. [CrossRef] [PubMed]

98. Shuang, Z.Y.; Wu, W.C.; Xu, J.; Lin, G.; Liu, Y.C.; Lao, X.M.; Zheng, L.; Li, S. Transforming growth factor- $\beta 1$-induced epithelial-mesenchymal transition generates ALDH-positive cells with stem cell properties in cholangiocarcinoma. Cancer Lett. 2014, 354, 320-328. [CrossRef] [PubMed] 
99. Su, J.; You, P.; Li, W.L.; Tao, X.R.; Zhu, H.Y.; Yao, Y.C.; Yu, H.Y.; Han, Q.W.; Yu, B.; Liu, F.X.; et al. The existence of multipotent stem cells with epithelial-mesenchymal transition features in the human liver bud. Int. J. Biochem. Cell Biol. 2010, 42, 2047-2055. [CrossRef] [PubMed]

100. Pasquier, J.; Abu-Kaoud, N.; Al Thani, H.; Rafii, A. Epithelial to Mesenchymal Transition in a Clinical Perspective. J. Oncol. 2015. [CrossRef] [PubMed]

(C) 2015 by the authors; licensee MDPI, Basel, Switzerland. This article is an open access article distributed under the terms and conditions of the Creative Commons by Attribution (CC-BY) license (http:/ / creativecommons.org/licenses/by/4.0/). 